\title{
ATMOSPHERIC HALOCARBONS: \\ A DISCUSSION WITH EMPHASIS ON CHLOROFORM
}

\author{
Yuk Ling Yung, Michael B. McElroy and Steven C. Wofsy \\ Center for Earth and Planetary Physics \\ Harvard University, Cambridge, Massachusetts
}

\begin{abstract}
Bleaching of paper pulp represents a major industrial use of chlorine and could provide an environmentally significant source of atmospheric halocarbons. The related global production of chloroform is estimated at $3 \times 10^{5}$ ton $\mathrm{yr}^{-1}$ and there could be additional production associated with atmospheric decomposition of perchloroethylene. Estimates are given for the ptoduction of methyl chloride, methyl bromide and methyl iodide, $5.2 \times 10^{6}, 7.7 \times 10^{4}$, and $7.4 \times 10^{5}$ ton $\mathrm{yr}^{-1}$ respectively. The relative yields of $\mathrm{CH}_{3} \mathrm{Cl}, \mathrm{CH}_{3} \mathrm{Br}$ and $\mathrm{CH}_{3} \mathrm{I}$ are consistent with the hypothesis of a marine biological source for these compounds. Concentrations of other halocarbons observed in the atmosphere appear to indicate industrial sources.
\end{abstract}

The atmosphere contains small though detectable quantities of $\mathrm{CCl}_{2} \mathrm{~F}_{2}$, $\mathrm{CCl}_{3} \mathrm{~F}, \mathrm{CH}_{3} \mathrm{Cl}, \mathrm{CH}_{3} \mathrm{CCl}_{3}, \mathrm{C}_{2} \mathrm{HCl}_{3}, \mathrm{C}_{2} \mathrm{Cl}_{4}, \mathrm{CH}_{3} \mathrm{I}, \mathrm{CCl}_{4}$, and $\mathrm{CHCl}_{3}$, with concentrations as summarized in Table 1 . The fluorocarbons, $\mathrm{CCl}_{2} \mathrm{~F}_{2}$ and $\mathrm{CCl}_{3} \mathrm{~F}$, are industrial in origin, employed primarily as refrigerants and as aerosol propellants (Lovelock, 1971; Lovelock et al., 1973; Wilkniss et al., 1973, 1974; Su and Goldberg, 1973; Rasmussen, 1975). Trichloroethylene perchloroethylene, and 1,1,1-trichloroethane are extensively used as solvents and dry-cleaning agents. Methyl chloride, $\mathrm{CH}_{3} \mathrm{Cl}$, and methyl iodide, $\mathrm{CH}_{3} \mathrm{I}$, appear to be produced mainly by marine biological activity (Lovelock, 1975; Rasmussen, 1975) and there is evidence for an analogous source of methyl bromide, $\mathrm{CH}_{3} \mathrm{Br}$ (Rasmussen, 1975; Wofsy et al., 1975). Carbon tetrachloride, $\mathrm{CCl}_{4}$, is used extensively as an intermediate in the manufacture of $\mathrm{CCl}_{2} \mathrm{~F}_{2}$ and $\mathrm{CCl}_{3} \mathrm{~F}$. An uncertain fraction of the $\mathrm{CCl}_{4}$ is inadvertantly released to the atmosphere and, with reasonable assumptions (Molina and Rowland, 1974a), can account for the abundance listed in Table 1, although there may be additional, natural, sources (Lovelock et al., 1973). Chloroform, $\mathrm{CHCl}_{3}$, was used estensively as an anesthetic for almost 50 years after its discovery in 1831 . In recent years it has been used mainly as an intermediate in the manufacture of penicillın, and various fluorocarbon refrigerants (Freon 22) and resins (notably Teflon).

This paper is concerned primarily with $\mathrm{CHCl}_{3}$. We shall attempt to define the magnitude and identify the nature of the source for this compound. There is an urgent need for a comprehensive study of atmospheric halocarbons, in light of the potentially important role which they may play in the chemistry of stratospheric ozone (Molina and Rowland, 1974, a, b; Wofsy et al., 1975). This paper describes an initial step towards this objective. It offers, in addition to the discussion of $\mathrm{CHCl}_{3}$, some updated estimates for the magnitude of the surface source required in order to account for the measurements of $\mathrm{CH}_{3} \mathrm{Cl}$ and $\mathrm{CH}_{3} \mathrm{I}$ given in Table 1 .

Chloroform will be removed from the atmosphere primarily by reaction with $\mathrm{OH}$, and similar remarks apply to $\mathrm{CH}_{3} \mathrm{Cl}$. Rate constants for the relevent reactions were measured recently at $296^{\circ} \mathrm{K}$ by Howard and Evenson (1975) and Davis et al. (1975). Their data, together with estimates for the relevent activation energies, were used to construct the rate constants listed in Table 2. The $\mathrm{OH}$ profile summarized in Figure 1 was computed in the manner described by McElsoy et al., (1974). The lifetime for $\mathrm{CH}_{3} \mathrm{I}$, determined mainly by photolysis, was computed using cross sections measured by Porret and Goodeve (1938). The lifetimes given in Table 2 represent upper limits. The actual values could be somewhat less if there were important loss processes in addition to photolysis and reaction with OH. In like manther the sources for $\mathrm{CH}_{3} \mathrm{Cl}, \mathrm{CH}_{3} \mathrm{I}$ and $\mathrm{CHCl}_{3}$ given in Table 2 represent lower limits and should be adjusted upwards if additional atmospheric sinks can be identified for these species. The sources for $\mathrm{CH}_{3} \mathrm{Cl}$ and $\mathrm{CH}_{3} \mathrm{I}$ given here may be compared with the source of $7.7 \times 10^{4}$ metric tons $\mathrm{yr}^{-1}$ derived earlier for $\mathrm{CH}_{3} \mathrm{Br}$ (Wofsy et al., 1975).

Table 2 includes two estimates for the global production of $\mathrm{CHCl}_{3}$. The Copyright 1975 by the American Geophysical Union
Table 1

Measurements of Halomethanes

\begin{tabular}{lcl}
\hline Species & $\begin{array}{c}\text { Mixing Ratio (v/v) } \\
\left(10^{-12}\right)\end{array}$ & \multicolumn{1}{c}{ Reference } \\
\hline $\mathrm{CCl}_{2} \mathrm{~F}_{2}$ & $102-115$ & Lovelock (1974) \\
\hline $\mathrm{CCl}_{3} \mathrm{~F}$ & $\begin{array}{c}60-80 \\
80-90\end{array}$ & $\begin{array}{l}\text { Wilkniss et al. (1973) } \\
\text { Lovelock (1974) }\end{array}$ \\
\hline $\mathrm{CH}_{3} \mathrm{Cl}$ & 400 & Lovelock (1975) \\
\hline $\mathrm{CH}_{3} \mathrm{I}$ & $550 \pm 50$ & Rasmussen (1975) \\
\hline & 1.2 & Lovelock (1973) \\
$\mathrm{CCl}_{4}$ & $71 \pm 7$ & Lovelock et al. (1973) \\
& $75 \pm 8$ & Wilkniss et al. (1973) \\
& $111-138$ & Lovelock (1974) \\
$\mathrm{CHCl}_{3}$ & $19-27$ & Lovelock (1974) \\
& 20 & Rasmussen (1975) \\
\hline
\end{tabular}

$1.5 \pm 1.2$

$\mathrm{C}_{2} \mathrm{HCl}_{3} \quad$ (Southern Hemisphere) Lovelock (1975)

(Northern Hemisphere)

$$
<1.5
$$

$\begin{array}{ccc}\mathrm{C}_{2} \mathrm{Cl}_{4} & \text { (Southern Hemisphere) } \\ 28 \pm 9 & \text { Lovelock (1975) }\end{array}$

(Northern Hemisphere)

$24 \pm 3$

(Southern Hemisphere)

$65 \pm 17$

(Northern Hemisphere)

larger value would be appropriate if there were globally dispersed sources for the gas, i.e. if the abundance listed in Table 1 were represéntative of mean atmospheric conditions. The smaller value assumes that $\mathrm{CHCl}_{3}$ is anthropogenic in origin and supposes that the source is restricted to populated areas of the northern hemisphere. We may note that even the smaller of the sources in Table 2 is significantly larger than the U.S. Tariff Commission's estimate for the total U.S. production of $\mathrm{CHCl}_{3}$ in $1972,1 \times 10^{5}$ tons. The discrepancy is particularly serious if we recall that most $\mathrm{CHCl}_{3}$ produced industrially is consumed in the manufacture of other chemicals. If we adopt McCarthy's (1975) estimate for the inadvertent release rate, about $50 \%$, we estimate a global source of atmospheric $\mathrm{CHCl}_{3}$ of $1 \times 10^{5}$ tons $\mathrm{yr}^{-1}$, significantly less than either of the values in Table 2 . It is hard to escape the conclusion that there must be sources of atmospheric $\mathrm{CHCl}_{3}$ in addition to those listed by the Tariff Commission. A summary of data on major industrial uses of chlorine is given in Table 3. As we may see below, the use of ohlorine in the bleaching of paper pulp shows most promise as a possible source for the chloroform listed in Table 1. The mechanism suggested here, the haloform reaction, was suggested by Morris (1975) as the source of $\mathrm{CHCl}_{3}$ and other haloforms produced during the chlorination of municipal water supplies (Rook, 1974; Bellar et al., 1974). 
Table 2

Lifetimes and Sources of Halocarbons

\begin{tabular}{|c|c|c|c|c|c|c|c|}
\hline & $\mathrm{CHCl}_{3}$ & $\mathrm{CH}_{3} \mathrm{Cl}$ & $\mathrm{CH}_{3} \mathrm{I}$ & $\mathrm{C}_{2} \mathrm{HCl}_{3}$ & $\mathrm{C}_{2} \mathrm{Cl}_{4}$ & $\mathrm{C}_{2} \mathrm{H}_{3} \mathrm{Cl}_{3}$ & $\mathrm{CHF}_{2} \mathrm{Cl}$ \\
\hline $\begin{array}{l}\text { Mixing ratio (v/v) } \\
\quad\left(10^{-12}\right)\end{array}$ & 20 & 500 & 1.2 & 15 & 28 & 45 & - \\
\hline Major sink & $\mathrm{CHCl}_{3}+\mathrm{OH}$ & $\mathrm{CH}_{3} \mathrm{Cl}+\mathrm{OH}$ & $\mathrm{CH}_{3} \mathrm{I}+h \nu$ & $\mathrm{C}_{2} \mathrm{HCl}_{3}+\mathrm{OH}$ & $\mathrm{C}_{2} \mathrm{Cl}_{4}+\mathrm{OH}$ & $\mathrm{C}_{2} \mathrm{H}_{3} \mathrm{Cl}_{3}+\mathrm{OH}$ & $\mathrm{CHF}_{2} \mathrm{Cl}+\mathrm{OH}$ \\
\hline Rate constant (a) & $\begin{array}{c}\mathrm{k}=1.0 \times 10^{-12} \\
\mathrm{e}^{-630 / \mathrm{T}}(\mathrm{b})\end{array}$ & $\begin{array}{c}\mathrm{k}=1.69 \times 10^{-12} \\
\mathrm{e}^{-1066 / \mathrm{T}} \text { (c) }\end{array}$ & $\mathrm{J}=6.0 \times 10^{-6}$ & $k=3 \times 10^{-12}(\mathrm{~d})$ & $k=1.3 \times 10^{-12}(d)$ & $\begin{array}{c}\mathrm{k}=8.2 \times 10^{-13} \\
\mathrm{e}^{-1200 / \mathrm{T}}(\mathrm{e})\end{array}$ & $\begin{array}{c}\mathrm{k}=1.2 \times 10^{-12} \\
\mathrm{e}^{-1640 / \mathrm{T}}(1)\end{array}$ \\
\hline Lifetıme (s) & $1.0 \times 10^{7}$ & $2.8 \times 10^{7}$ & $1.7 \times 10^{5}$ & $3.7 \times 10^{5}$ & $8.5 \times 10^{5}$ & $9.5 \times 10^{7}$ & $3.0 \times 10^{8}$ \\
\hline $\begin{array}{l}\text { Source (if globally } \\
\text { distributed) } \\
\left(10^{6} \text { metric ton/yr) }\right.\end{array}$ & 0.99 & 5.2 & .74 & 31 & 31 & 0.4 & - \\
\hline $\begin{array}{l}\text { Source (if spatially } \\
\text { restricted, see } \\
\text { text) } \\
\left(10^{6} \text { metric ton } / y r\right)\end{array}$ & 0.23 & - & - & $1.0(\mathrm{~h})$ & $1.0(\mathrm{~h})$ & - & - \\
\hline
\end{tabular}

(a) Bimolecular rate constants, $k$, and dissociation rate, $J$, are in units $\mathrm{cm}^{3} \mathrm{~s}^{-1}$ and $\mathrm{s}^{-1}$ respectively.

(b) Howard and Evenson (1975) (at $296^{\circ} \mathrm{K}$ ) combined with an estimate of activation energes.

(c) Davis et al., (1975).

(d) Adjusted to the industrial source strength. These rates are consistent w1th those measured by Howard and Evensen (1975) for other haloethylenes.

(e) Estimate by C. Howard, private communication, 1975 .

(f) McCarthy, 1975.

(g) McConnell, 1975.

(h) Sources restricted to populated area and planetary boundary layer $\left(\sim_{1} \mathbf{k m}\right.$ thick)

(i) R. Atkinson, D.A. Hansen and J.N. P1tts, J. Chem. Phys. (in press, 1975).

The reaction sequence begins with

$$
\mathrm{Cl}_{2}+\mathrm{HCO}_{3}{ }^{-} \rightarrow \mathrm{HOCl}+\mathrm{Cl}^{-}+\mathrm{CO}_{2}
$$

followed by

$$
\mathrm{HOCl} \rightleftarrows \mathrm{H}^{+}+\mathrm{OCl}^{-}
$$
of complicated reactions involving dissolved . tions may be written symbolically in the form

$$
\mathrm{CH}_{3} \mathrm{COR}+3 \mathrm{HOCl} \rightarrow \mathrm{CCl}_{3} \mathrm{COR}+3 \mathrm{H}_{2} \mathrm{O}
$$

followed by

$$
\mathrm{CCl}_{3} \mathrm{COR}+\mathrm{H}_{2} \mathrm{O} \rightarrow \mathrm{CHCl}_{3}+\mathrm{RCOOH}
$$

Other reactions may lead to formation of additional halogenated species and it is interesting to note that a recent survey by the EPA (Symons, 1975) found evidence for some 35 compounds in the municipal waters of Miami, Florida. These compounds included $\mathrm{CHCl}_{3}, \mathrm{CHCl}_{2} \mathrm{Br}, \mathrm{CHClBr}_{2}$,

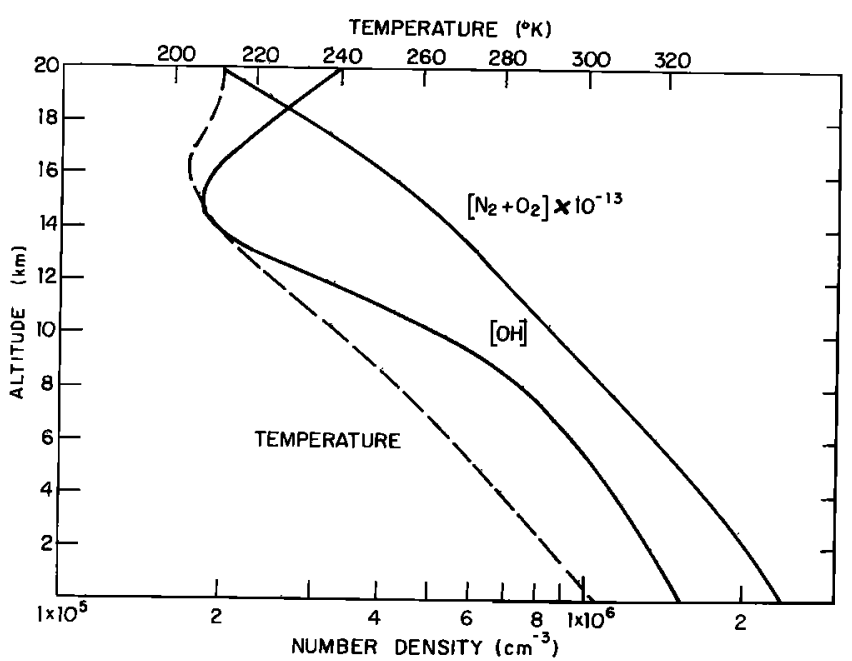

Figure 1: Model atmosphere and $\mathrm{OH}$ profile (see text). and $\mathrm{CHBr}_{3}$, and there are reasons to believe that a similarly rich suite of halogenated compounds would be formed during the bleaching of paper pulp. The bleaching process, combining an abundant source of organic material with an ample supply of chlorine at high $\mathrm{pH}$, would appear to provide an ideal medium for the production of the halocarbons of interest here. The yield of $\mathrm{CHCl}_{3}$ in chlorination of water is about $1-3 \%$ by weight according to Symons' data (1975). This result represents a lower limit to the potential conversion efficiency since the production of haloforms in the treatment of municipal water supplies appears to be limited by the availability of dissolved organic material. A conversion efficiency as low as $6 \%$ in the bleaching process would supply a global source of $\mathrm{CHCl}_{3}$ of magnitude $3 \times 10^{5}$ tons year $^{-1}$ and could account for the concentration of the gas given in Table 1 .

Decomposition of perchloroethylene, $\mathrm{Cl}_{2} \mathrm{C}=\mathrm{CCl}_{2}$, could provide an additional source for atmospheric $\mathrm{CHCl}_{3}$. Perchloroethylene is widely used as a solvent, with annual rates for release in excess of $10^{6}$ tons (U.S. Tariff Commission). Howard and Evenson (1975) found that halogenated ethylenes react with $\mathrm{OH}$ at rates faster than $10^{-12} \mathrm{~cm}^{3} \mathrm{sec}^{-1}$ to form the $\mathrm{OH}$ addition compound. The addition reaction should be faster than photolysis

Table 3

Production and major industrial uses of chlorine for the United States in 1974 (Klingnan, 1975).

\begin{tabular}{lc}
\multicolumn{1}{c}{ Major Uses } & Quantity $\left(10^{6}\right.$ metric tons $)$ \\
\hline Solvents & 2.68 \\
Plastics and synthetics & 2.19 \\
Paper products $^{1}$ & 1.78 \\
Automobile fluids $^{2}$ & .96 \\
Water and sanitation $_{\text {Agriculture }}$ & .59 \\
Miscellaneous & .49 \\
TOTAL & 1.18 \\
\hline
\end{tabular}

${ }^{1}$ According to B. Slatıng of American Paper Institute, N.Y. this chlorine is used for bleaching paper pulp.

${ }^{2}$ Mainly used to produce automobile anti-freeze (ethylene glycol) and ant1-knock 
(Tyerman, 1969) and should be more efficient also than possible competing reactions with ozone. The fate of the radical $\mathrm{CCl}_{2}-\mathrm{CCl}_{2} \mathrm{OH}$ has not been studied in any detail. A number of experiments however (Dahlberg et al., 1970; Dahlberg, 1969; Mathias et al., 1974; Haszeldine and Nyman, 1959) suggest that dichloroacetyl chloride, $\mathrm{HCl}_{2} \mathrm{C}-\mathrm{C}-\mathrm{O} \mathrm{Cl}$, should be a major product. Photolysis of dichloroactyl chloride

$$
h \nu+\mathrm{HCl}_{2} \mathrm{C}-\mathrm{C} ₹ \mathrm{Cl} \rightarrow \mathrm{CO}+\mathrm{CHCl}_{3}
$$

should take place at wavelengths as long as $3600 \AA$ (cf. Capey et al., 1968) and could provide a significant source of atmospheric $\mathrm{CHCl}_{3}$. A quantitative estimate for this source would however require a careful analysis of competing loss processes for $\mathrm{HCl}_{2} \mathrm{C}-\mathrm{C}_{\mathrm{Cl}}^{\infty}$. The source strength estimates in Table 2 are consistent with industrial origin for $\mathrm{C}_{2} \mathrm{Cl}_{4}, \mathrm{C}_{2} \mathrm{HCl}_{2}$, and $\mathrm{CH}_{3} \mathrm{CCl}_{3}$ in the atmosphere.

It is of interest to examine possible natural sources of halogenated compounds. The oceans contain $2 \times 10^{-2}, 7 \times 10^{-5}$ and $3-7 \times 10^{-8}$ parts by weight of chlorine, bromine and iodine respectively. Seaweeds have long been known for their abjlity to concentrate bromine and iodine. The enrichment factors, defined with respect to the concentrations in sea water, are typically in the range $2-10$ for bromine and $10^{3}-3 \times 10^{4}$ for iodine (Hoppe, 1969). It appears that the concentration of chlorine in sea weed is sumilar to that in the overall marine environment (Shaw, 1962). Wof sy et al. (1975) estimated a marine production of methyl bromide of magnitude $7.7 \times 10^{4}$ ton $\mathrm{yr}^{-1}$ and combining their data with the results of Table 2 we find production rates by weight for $\mathrm{CH}_{3} \mathrm{Cl}, \mathrm{CH}_{3} \mathrm{Br}$ and $\mathrm{CH}_{3} \mathrm{I}$ in the ratio 1:.015:.14, within the present limits of uncertainty, consistent with the halogen composition of algae. $\dagger$ There are no known natural sources for chloroform, although we may note that $\mathrm{CHBr}_{3}$ is a major constituent in the essential oil of the red alga Asparagopsis taxiformis, which includes in addition, detectable amounts of $\mathrm{CHClBr}_{2}, \mathrm{CHClBrI}, \mathrm{CHBr}_{2} \mathrm{I}, \mathrm{CHBrI}_{2}$, and $\mathrm{CHI}_{3}$ (Burreson et al., 1975). The abundance of $\mathrm{CHCl}_{3}$ listed in Table 1 would supply a source of stratospheric chlorine which could account for a global reduction in ozone by as much as $0.04 \%$. Corresponding values for the reduction in ozone due to marine biological production of methyl chloride and methyl bromide are $0.8 \%$ and $0.5 \%$ respectively and the present day reduction due to $\mathrm{CFCl}_{3}$ and $\mathrm{CF}_{2} \mathrm{Cl}_{2}$ is $0.6 \%$. These considerations serve to emphasize the need for a comprehensive definition of the atmospheric halogen budget. It is clear that the reservoir includes contributoons from a variety of natural and anthropogenic activities ranging from certain functions of marine algae to the preparation of paper, the fumigaton of agricultural soil and the large scale commercial application of aerosol sprays and refrigerants.

\section{Acknowledgement}

We are indebted particularly to J.C. Morris who shared readily with us his remarkable insights into the chemistry of chlorinated water. We thank C.L. Klingman for providing us with the contents of Table 3, and R. Rasmussen for making available his unpublished measurements. The work was supported in part by the Atmospheric Sciences Division of the National Science Foundation under Grant GA33990X and by the National Aeronautics and Space Administration under Grant NASA NSG 2031 to Harvard University.

\section{References}

Bellar, T.A., J.J. Lichtenberg and R.C. Kroner, 1974: The эccurence of organohalides in finished drinking waters. J. Am. Water Works Assn., 66,703 .

Burreson, B.J., R.E. Moore and P. Roller, 1975: Haloforms in the essential oil of the alga Asparagopsis Taxiformis (Rhodophyta). Tetrahedron Lett., 7, 473.

Capey, W.D., J.R. Majer and J.C. Robb, 1968: Photolysis of acetyl chloride.J. Chem. Soc., (B), 1968, 447.

Dahlberg, J.A., 1969: The non-sensitized photo-oxidation of trichloroethylene in air. Acta Chem Scan., 23, 3081-3090.

$\dagger$ In the present estimate we note that $\mathrm{CH}_{3} \mathrm{I}$ has a lifetime short compared with the tume required for vertical mixing. Consequently we assume that $\mathrm{CH}_{3} \mathrm{I}$ is confined to the planetary boundary layer $(\sim 1 \mathrm{~km}$ thıck). Our estimate for the production of methyl iodide is consistent with the remainder of the total budget for iodine (Miyake and Tsunogai, 1963) and agrees also with the recent study of flux gases across the air-sea interface (Liss and Slater, 1974). Earlier estimates (Lovelock et al., 1973, Zafiriou, 1974) appear to have seriously overestimated the source of methyl iodide.
Dahlberg, J.A. and I.B. Kihlman, 1970: Gas chromatographic determination of chlorinated acetyl chlorides and phosgene present in air in very low concentrations. Acta Chem. Scand., 24, 644-650.

Davis, D.D., R.T. Watson, et al., 1975: private communication.

Haszeldine, R.N. and F. Nyman, 1959: Oxidation of polyhalogeno compounds part II photolysis and photochemical oxudation of some chlorofluoromethanes.J. Am. Chem. Soc., 81, 387.

Hoppe, H.A., 1969: Marine Algae, A survey of Res, and Utilization. Ed. by T. Levring, H.A. Hoppe and O. Schmid. Cram, DeGruyter \& Co.

Howard, C J. and K.M. Evenson, 1975: private communication.

Klingman, C.L., 1975: Mineral Facts and Problems, Bureau of Mines, U.S. Dept. of the Interior. To be published.

Liss, P.S. and P.G. Slater, 1974: Flux of gases across the air-sea interface. Nature, 247, 181

Lovelock, J.E., 1971: Atmospheric fluorine compounds as indicators of air movement. Nature, 230, 379.

Lovelock, J.E., R.J. Maggs, and RJ. Wade, 1973: Halogenated hydrocarbons in and over the Atlantic. Nature, 241, 194.

Lovelock, J.E., 1974: Atmospheric halocarbons and stratospheric ozone. Nature, 252, 292.

Lovelock, J.E., 1975: private communication.

McCarthy, R.L., 1975: private communication.

MacMillan, R.T., 1970: "Chlorine", Mineral Facts and Problems, Bureau of Mines, U.S. Dept of the Interior.

Mathias, E., E. Sanhueza, I.C. Hisatsune and J. Heicklen, 1974: The chlorine atom sensitized oxidation and the ozonolysis of $\mathrm{C}_{2} \mathrm{Cl}_{4}$. Can J. Chem., 52, 3852.

McConnell, G., D.M. Ferguson, and C.R. Pearson, 1975: Chlorinated hydrocarbons and the environment. Endeavor, 34, 13.

McElroy, M.B., S.C. Wofsy, J.E. Penner, and J.C. McConnell, 1974 Atmospheric ozone: possible impact of stratospheric aviation. $J$. Atmos. Sci., 31, 287.

Miyake, Y. and S. Tsunogai, 1963: Evaporation of iodine from the ocean J. Geophys. Res., 68, 3989.

Molina, M.J., and F.S. Rowland, 1974: Stratospheric sink for chlorofluoromethanes: chlorine atom-catalysed destruction of ozone, Nature. 249,810 .

Molina, MJ. and F.S. Rowland, 1974: Predicted present stratospheric abundances of chlorine species from dissociation of carbon tetrachloride. Geophys. Res. Lett., $1,309$.

Morris, J.C., 1975: Formation of halogenated organics by chlorination of water supplies: a review.

Draft report to Office of Research and Development, EPA (RD 683) Washington, D.C.

Porret, D. and C.F. Goodeve, 1938: The continuous absorption spectrum of methyl iodide. Proc. Roy. Soc. (London) A 165, 31.

Rasmussen, 1975: private communication.

Rook, J.J., 1974: Formation of haloforms during chlorination of natural waters. Water Treatment Exam., 23, 234.

Shaw, T.I., 1962: "Halogens" Physiology and Biochemistry of Algae, Ed. R.A. Lewin. Academic Press, New York.

$\mathrm{Su}$, Chih-Wu, and E.D. Goldberg, 1973: Chlorofluorocarbons in the atmosphere. Nature, 245, 27.

Symons, J.M., 1975: Suspect carcinogens in water supplies. Interim report to Congress. Water Supply Research Laboratory, National Env. Research Center. Office of Research and Development, Cincinnati, Ohio.

Tyerman, WJ.R., 1969: Flash photolysis of haloethylenes Trans. Farad. Soc., 65, 2948.

Wilkniss, P.E., R.A. Lamontagne, R.E. Larson, J.W. Swinnerton, C.R. Dickson and T. Thompson, 1973: Atmospheric trace gases in the southern hemisphere. Nature, 245, 45 .

Wofsy, S.C., M.B. McElroy and N.D. Sze, 1975: Freon consumption: implications for atmospheric ozone. Science, 187, 535.

Wofsy, S.C., M.B. McElroy and Y.L. Yung, 1975: The chemistry of atmospheric bromine. Geophys. Res. Let. 2, 215.

Zafiriou, O.C., 1974: Photochemistry of halogens in the marine atmosphere. J. Geophys. Res., 79, 2730.

(Received June 12, 1975; accepted August 7, 1975.) 